\title{
Economic efficiency assessment of projects for the information systems creation
}

\author{
0. Kultygin ${ }^{\text {* }}$ \\ 1 Synergy University, Moscow, Russia \\ *OKultygin@synergy.ru
}

\begin{abstract}
The article is concerned with an approach to assess the economic efficiency of IT projects, which results are recommended to be used when choosing the informatization version for organizations of various types. This approach is based on the calculation of such indicators as capital costs for an IT project, the magnitude of the projected change in operating costs to ensure the functioning of the IS (information system), the growth rate in the efficiency of business processes as a result of informatization, as well as the costs to ensure the required level of information security. The analysis results of modern trends in the IS development for informatization of organization business processes are given, which made it possible to identify the main features of the solutions offered on the market. The analysis of direct and indirect costs for an IT project is shown to be rather difficult in a number of cases, which leads to inaccuracies in assessing its economic efficiency. In this case, the estimated payback period of the project (usually unreasonably short) can be exceeded many times in practice. At the same time, as a result of rapid progress in the field of information technology, the IT projects results are subjected to intense obsolescence, so long payback periods can lead to significant losses for the organization implementing the project. The consideration of the influence of the information security threats and the necessary additional funds for its provision on the forecast indicators for the economic efficiency of the proposed IT projects can significantly affect the decisions on choosing not only the configuration of the IS but the platform on which it operates as well. The article proposes an approach to determine the costs for ensuring information security, which should be considered when assessing the IT project economic efficiency. A mathematical model is described to choose an option for the tables rational placement on IS units (database servers) used by employees of various geographically detached divisions of an enterprise, which will allow reducing operating costs for this system operation.
\end{abstract}

Keywords: information system, informatization efficiency assessment, information security, IT project, database management systems

For citation: Kultygin 0. Economic efficiency assessment of projects for the information systems creation. Prikladnaya informatika=Journal of Applied Informatics, 2021, vol.16, no.5, pp.117-125. DOl: 10.37791/26870649-2021-16-5-117-125 


\title{
Оценка экономической эффективности проектов по созданию информационных систем
}

\author{
О. П. Култыгин ${ }^{1 *}$ \\ 1 Университет «Синергия», Москва, Россия \\ *OKultygin@synergy.ru
}

\begin{abstract}
Аннотация. В статье рассмотрен подход к оценке экономической эффективности ИТ-проектов, результаты которого рекомендуется использовать при выборе варианта информатизации организаций различного типа. Указанный подход основан на расчете таких показателей, как капитальные затраты на ИТ-проект, размер прогнозируемого изменения эксплуатационных расходов по обеспечению функционирования ИС, величина роста эффективности бизнес-процессов в результате информатизации, а также затраты на обеспечение требуемого уровня информационной безопасности. Приведены результаты анализа современных тенденций развития ИС для информатизации бизнес-процессов организации, которые позволили выявить основные особенности предлагаемых на рынке решений. Показано, что в ряде случаев анализ прямых и косвенных затрат по ИТпроекту достаточно затруднен, что приводит к неточностям при оценке его экономической эффективности. В этом случае предполагаемые сроки окупаемости проекта (обычно необоснованно короткие) на практике могут быть многократно превышены. В то же время в результате быстрого прогресса в сфере информационных технологий результаты ИТпроектов подвержены интенсивному моральному износу, поэтому длительные сроки их окупаемости могут привести к существенным потерям для организации, реализующей проект. Учет влияния угроз информационной безопасности и необходимых дополнительных средств на ее обеспечение на прогнозные показатели экономической эффективности предлагаемых к реализации ИТ-проектов может существенно повлиять на решения по выбору не только конфигурации ИС, но и платформы, на которой она функционирует. В статье предложен подход к определению затрат на обеспечение информационной безопасности, которые должны быть учтены при оценке экономической эффективности ИТ-проекта. Описана математическая модель для выбора варианта рационального размещения по узлам ИС (серверам баз данных) таблиц, используемых сотрудниками различных территориально обособленных подразделений предприятия, что позволит снизить эксплуатационные расходы на функционирование указанной системы.
\end{abstract}

Ключевые слова: информационная система, оценка эффективности информатизации, информационная безопасность, ИТ-проект, системы управления базами данных

Для цитирования: Култыгин О. П. Economic efficiency assessment of projects for the information systems creation // Прикладная информатика. 2021. T. 16. № 5. C. 117-125. DOI: 10.37791/2687-0649-2021-16-5$117-125$

\section{Problem statement}

$\mathrm{n}$ the context of the economy large-scale digitization, the problem of choosing a version for creating a new information system (IS) or developing an existing information one or its modules is an urgent task to organize various types of economic activity. Obviously, this choice should be based on the results of the project economic efficiency analysis for the informatization of the organization 